\title{
Note about Forum Philosophicum
}

\section{Mission STATEMENT}

Forum Philosophicum is a scholarly journal that seeks new insights into philosophical discussions concerning the relationship between philosophy and faith. The tradition we are rooted in is that of Christian philosophy, understood as the independent exercise of reason in the context of the faith. However, we also welcome proposals that flow from the concerns important to philosophers shaped by other religious traditions, in particular those of Jewish or Muslim heritage. We seek articles that are able to engage in critical debate with evolving views on rationality and its relationship to the irrational, the indeterminate, and the non-binary, and look forward to receiving analyses that discuss the place of faith and the rationality of faith in such contexts. We encourage discussions of human nature and spirituality that seek to address the proposals of neuroscience and confront the declarations of posthumanists, as well as inquiries into that mode of philosophizing which, while resting on the hermeneutics of culture, gives special emphasis to the hermeneutics of sacred texts. We would like to distinguish our journal by means of its unique approach, rather than through the specificity of the subjects we are prepared to see raised in it: an approach that allows faith to shape, enlighten, and strengthen rationality itself. In this way, we want to offer a true Forum for the community of philosophers who view their faith as a source of inspiration, especially when seeking to face up to the new and challenging forms being given to the age-old problems of philosophy.

Forum Philosophicum is published in English by Ignatianum University Press, part of the Jesuit University Ignatianum in Krakow. Its two annual issues, published in June and December, together furnish around 30 papers. Until recently, these were published in a range of languages recognized as appropriate for international conferences, but as of 2011 the journal has 
accepted papers exclusively in English. It is, in its basic version, a traditional print-based journal, but also has a parallel online version, available via the EBSCO Academic Search Complete electronic database (since vol. 6, 2001) and the Philosophy Documentation Center online subscription service (since vol. 1, 1996). Since vol. 23, 2018, all articles have been published in full open-access model based on Creative Commons Attribution (BY) license. Selected earlier articles are published in open access on the journal's website. The journal is also indexed in, among others, The Philosopher's Index, Atla Religion Database, and the PhilPapers database.

\section{SubMissions}

Forum Philosophicum only accepts submissions in English. We publish papers, cycles of papers, discussions and book reviews. Papers submitted for consideration in Forum Philosophicum cannot exceed 15,000 words, including footnotes and bibliography. They should be preceded by an abstract not exceeding 200 words. Manuscripts should be submitted via e-mail to the following address:

forum.philosophicum@ignatianum.edu.pl All papers accepted for publication will go through a linguistic review process to ensure the utmost clarity and accessibility of submissions. MORE INFORMATION about submissions and guidelines for authors may be found at http://forumphilosophicum.ignatianum.edu.pl/submissions

\section{EDITORIAL BOARD}

Jacek Surzyn, Editor-in-Chief

Jesuit University Ignatianum in Krakow, Poland Jakub Pruś, Secretary and Associate Editor

Jesuit University Ignatianum in Krakow, Poland

Férdia Stone-Davis, International Assistant Editor

Margaret Beaufort Institute of Theology, Cambridge, UK

Daniel Spencer, International Assistant Editor

University of St Andrews, UK

Rev. Mark Sultana, International Assistant Editor

University of Malta, Faculty of Theology, Malta

Magdalena Jankosz, Language Editor

Pontifical University of John Paul II, Poland

Szczepan Urbaniak SJ, Associate Editor for Phenomenology

Jesuit University Ignatianum in Krakow, Poland 
Advisory BOARD

Andreas Wilmes

West University of Timisoara, Romania

Christopher Wojtulewicz

Katholieke Universiteit Leuven, Belgium

Marcin Podbielski,

Jesuit University Ignatianum in Kraków, Poland

Petr Dvořák

Academy of Sciences of the Czech Republic

Dariusz Łukasiewicz

Kazimierz Wielki University in Bydgoszcz, Poland

David Pratt

Georgetown University, WA, USA

Andrey Tikhonov

Southern Federal University at Rostov-on-Don, Russia

Elizabeth Burns

Department of Theology and Religious Studies, King's College

London, UK

Alex R Gillham

St. Bonaventure University, NY, USA

Joeri Schrijvers,

North-West University of Potchefstroom, South Africa

Till Kinzel,

Technische Universität Braunschweig, Germany

CONTACT INFORMATION

Forum Philosophicum, Beyzymówka, p. 3

Jesuit University Ignatianum in Krakow

ul. Kopernika 26, 31-501 Kraków, Poland

E-MAIL forum.philosophicum@ignatianum.edu.pl

PHONE $+48123999661 \quad$ FAX +48123999501

www https://forumphilosophicum.ignatianum.edu.pl

ONLINE VERSION http://pdcnet.org/forphil

PUblisher INFORMATION

Wydawnictwo Naukowe Akademii Ignatianum w Krakowie Zofijówka Office 6, ul. Kopernika 26, 31-501 Kraków (Poland)

tel. 123999 620, fax 123999501

e-mail:wydawnictwo@ignatianum.edu.pl 


\section{REVIEW PROCESS}

The review process for papers submitted to Forum Philosophicum adheres to the following guidelines:

1. A paper submitted to the Editor may be returned to the author if it does not meet the criteria described in the section Sumbissions, or if it does not discuss a topic within a subject-area of interest to Forum Philosophicum.

2. Each paper will be sent to two reviewers for blind review. At least one of the reviewers must be affiliated to an institution in a different country than the author.

3. Members of the Board, including the Editor, are not allowed to write reviews. No specialist who is known to be related to the author or who may reasonably be thought to have collaborated with the author or supervised his / her work is eligible as a reviewer.

4. Reviewers are explicitly asked to focus on the research and philosophical merits of a paper; they are told that any linguistic and/or technical deficiencies pertaining to an otherwise good paper may be dealt with separately by the editors.

5. The reviewers are asked to conclude their review with a clear opinion, stating that a paper is (a) publishable without revisions, or (b) may be published after minor revisions have been introduced, or (c) may be resubmitted after major revision, or (d) should not be considered for publication at all.

6. The final decision concerning which of the papers that have obtained at least one positive review are to be published is taken by the Editorin-Chief, in consultation with the Editorial Board.

7. The names and affiliations of all reviewers are published annually in the Autumn issue and on the website of the journal.

\section{LEGAL ISSUES}

Copyright Forum Philosophicum is published by Ignatianum University Press under a Creative Commons Attribution 4.0 International License. Authors of papers that have been accepted will be asked to grant the publisher the royalty-free right to first publication, as well as a non-exclusive right to distribute and archive the paper in electronic format, including through organizations specializing in the distribution and archiving of scholarly journals.

It should be understood that the fact of publication constitutes the sole form of remuneration to be received by authors. Authors will also receive three print copies of the issue containing the published paper and a PDF file 
of their paper, which may be freely redistributed. Papers first published in Forum Philosophicum may be republished without asking permission from Ignatianum University Press. The authors and publishers are requested to mention Forum Philosophicum as the place of initial publication.

\section{FINANCING}

All authors whose research is supported by special sources of financing, such as grants, research programs, etc., are asked to prepare an information note mentioning the support they have received. Originality Forum Philosophicum will only accept manuscripts of papers not previously published in, or submitted to and still currently under review by, another journal or collection.

The Polish Ministry of Science and Higher Education requires the editors of all Polish journals which they evaluate to follow certain basic rules of scientific honesty, as defined by Committee on Publication Ethics. While we strongly believe that the authors submitting papers to Forum have no intention whatsoever of breaking those rules, and while the rules pertaining to joint authorship are rarely applicable to papers submitted to a philosophical journal, we consider it important to reiterate some of those rules to our authors. Thus, we remind authors that it is not acceptable to submit papers that reflect anything other than original research or reflections conducted by the author himself / herself. Concealing the true authorship of a part of a paper, even if the paper is in itself an original contribution, also constitutes a breach of such rules. Since all papers are reviewed by specialists, those seeking to make a submission should work on the assumption that any and all instances of plagiarism or ghost-writing will be detected. For jointly authored papers, a clear indication must be given in the paper itself of the manner and extent of each and every author's contribution. Papers with so-called "guest authors," whose contribution to the thesis of the paper is actually minimal, cannot be accepted. All cases of academic dishonesty, if detected, will be reported to the organizations with which the authors are affiliated. 


\section{SUBSCRIPTIONS}

Since 1 January 2018, subscriptions are managed by Ignatianum University Press.

ANNUAL SUBSCRIPTION FEE RATES Libraries and institutions: $60 \mathrm{zł} \mathrm{(Poland),}$ $€ 40$ (Rest of Europe), \$ 60 (Rest of the World). Individuals: $40 \mathrm{zł}$ (Poland), $€ 20$ (Europe), \$ 30 (The Rest of the World)

SUbSCRIPTION REQUESTS should be sent to the following address:

Ignatianum University Press

Jesuit University Ignatianum in Krakow

ul. Kopernika 26

31-501 Krakow, Poland

E-MAIL wydawnictwo@ignatianum.edu.pl

FAX $(+48) 123999620$

PHONE: (+48) 123999501

PAyment must be made by money transfer. International cheques are no longer accepted by most banks in Poland. Money should be wired to the account of Akademia Ignatianum w Krakowie (Jesuit University Ignatianum in Krakow). For foreign transfers, please use the following banking details:

Recipient: Akademia Ignatianum w Krakowie, Prenumerata „Forum Philosophicum”

Address: ul. Kopernika 26, 31-501, Kraków, Poland

IBAN account number: PL 94249000050000460098711366

SWIFT: ALBPPLPW

Bank Name: Alior Bank SA

Title: Forum Philosophicum \{subscriber and period of subscription\} Dane dLA PRZelewów w Polsce

Nr rachunku: 94249000050000460098711366

Odbiorca: Akademia Ignatianum w Krakowie, Prenumerata "Forum Philosophicum"

Adres: ul. Kopernika 26, 31-501, Kraków

Tytuł przelewu: Forum Philosophicum, Imię Nazwisko i adres subskrybenta

All payments should be accompanied by an e-mail or a letter confirming the mailing address and the period for which the subscription is being purchased.

ELECTRONIC VERSION Electronic subscriptions are managed by our partners, Philosophy Documentation Center and EBSCO Information Services. 